\section{Evaluating the effectiveness of an educative workshop for pregnant women using pre and post intervention surveys}

\author{
Avaliação da efetividade de uma oficina educativa \\ para gestantes com o uso de inquéritos pré- \\ e pós-intervenção
}

\section{Evaluando la efectividad de un taller educativo para mujeres embarazadas utilizando pre y post encuestas de intervención}

\begin{abstract}
This paper will report the findings of an education intervention performed by a workshop aimed to provide pregnant women with knowledge about pregnancy, delivery, breastfeeding and newborn care. A cross-sectional study, using a pre and post-intervention research design, was performed with 105 pregnant women from an obstetric service for a two-year period. Time points (pre and post) were compared using either Student t test and ANOVA. Significance was set at $p \leq 0.05$. After the intervention all items increased their level from the three stations: antenatal care (20.4\%), labor and delivery (36.8\%) and postnatal and breastfeeding (32.1\%). The total score of the surveys also increased $31.7 \%$ when comparing the pre and post applications $(p<0.001)$. It was evidenced the importance of strategies to improve knowledge about pregnancy and its surroundings to pregnant women. The workshop proposal presented increases in its knowledge and can most likely bring better results in short and long-term outcomes.
\end{abstract}

Pregnant Women; Health Education; Pregnancy Complications;

Breast Feeding
Rodrigo Dias Nunes 1

Ana Gabriela Puel 1

Natália Gomes 1

Jefferson Traebert 1

doi: 10.1590/0102-311X00155018

\section{Correspondência}

R. D. Nunes

Universidade do Sul de Santa Catarina.

Av. Pedra Branca 25, Cidade Universitária, Palhoça, SC 88137-270, Brasil.

rodrigo.dias.nunes@hotmail.com

1 Universidade do Sul de Santa Catarina, Palhoça, Brasil. 


\section{Introduction}

Many adverse outcomes in pregnancy are related to the lack of knowledge regarding pregnancy itself, labor, delivery and lactation period 1 , such as inadequate development, low birth weight and increased risk of developing chronic diseases later in life 2.

According to the World Health Organization, consultation length is an indicator of quality of the provided health care 3 . Assuming that much of the knowledge a pregnant woman needs may not be provided. But, since the information cannot be offered during regular appointments, it is necessary to carry out complementary activities 4 .

It is the responsibility of health professionals to participate in activities promoting community mobilization and participation in continuing education activities. These activities potentiate maternal and perinatal outcomes, regardless of the medical specialty performing prenatal care 5 . Otherwise, in daily practice health care providers rarely mention anything beyond technical information during antenatal visits 6 .

This study aimed to report the findings of a workshop to provide knowledge about pregnancy, delivery, breastfeeding and newborn care to pregnant women, comparing the level of knowledge among pregnant women using pre and post educational intervention surveys.

\section{Methods}

This workshop is part of a continuing educational program of antenatal care for pregnant women attending the service at the University of Southern Santa Catarina in the city of Palhoça, Santa Catarina State, Brazil. These women are regularly being followed at their prenatal outpatient clinic, sent by the Municipal Primary Care Units.

A cross-sectional study, using a pre and post-intervention research design was used to observe the level of knowledge about the characteristics of the pregnancy-puerperal period. Self-reported surveys were used to collect data before and after the workshop in a convenience sample obtained with all pregnant women attending the antenatal service $(n=105)$. The workshop participation was part of this institution's prenatal care program and all women were recruited, happening every five weeks.

Women were asked to answer the pre-workshop survey in a 5-point Likert scale, ranging from "strongly disagree" to "completely agree". It was composed by 26 items regarding antenatal care (8-item); labor and delivery (9-item) and breastfeeding and newborn care (9-item). There was no right answer because they were used to compare both surveys (Box 1).

The main workshop theme was the perinatal care, involving antenatal care, labor and delivery and post-natal and breastfeeding. It was developed by a group of experts in obstetrics, such as medical doctors, midwiferies, professors from the maternal-infant system, medical students and primary care professionals. The workshop content was based on the recommendations from the Ministry of Health addressed during prenatal care, to ensure the development of pregnancy, allowing the delivery of a healthy newborn, without impact on maternal health, which include addressing psychosocial aspects and educational and preventive activities 5 . Issues were elaborated by the team that coordinates and executes educational and care actions, from the experience perceived by the years at this public clinic reinforced by the guidelines from the Brazilian Ministry of Health, regarding the good practices on the ante-natal care.

The workshop was divided into three one-hour meetings in three simultaneous rooms. The first part of each meeting was conducted by an obstetrician, professor from the maternal-infant system. The first 10 minutes of each meeting were dedicated to present an introduction of each theme. Four medical students from the 4th year conducted the second part of each meeting and acted as stimulators of the discussion. Each group was formed by 10 pregnant women and their partners or relatives. At this time, students presented their pre-prepared audio-visual material, working as conductors of the focal group of discussion. Women and conductors were accommodated in big circles, in each room, in order to facilitate interrelation. Any subject and doubt raised by the participants were included simultaneously. 
Box 1

Evaluation survey to estimate knowledge improvement with the workshop.

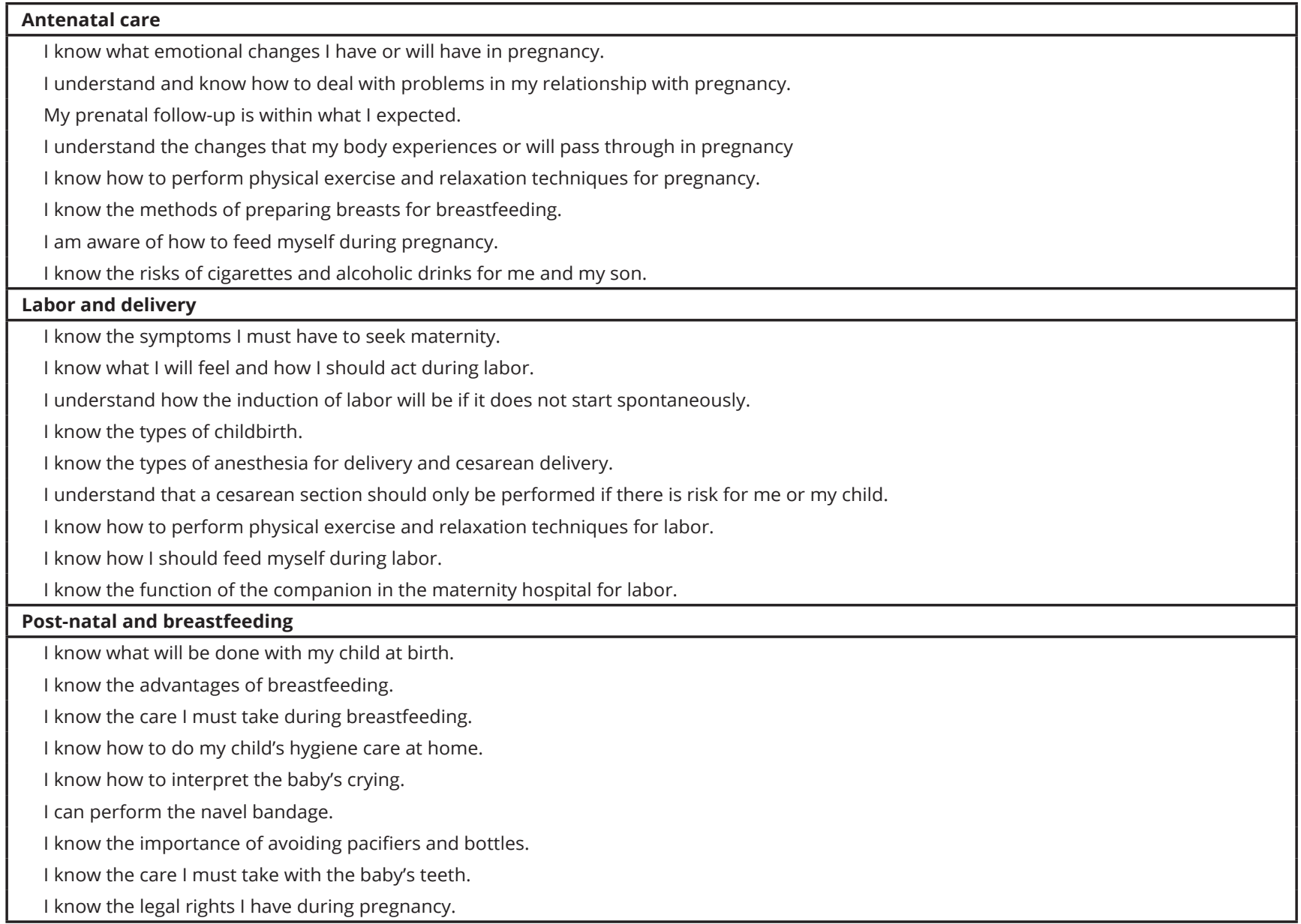

The meeting involving antenatal care addressed emotional and physical changings, relationships, expectations, dietary, behavior aspects and breast preparation. The meeting regarding labor and delivery addressed types of birth, induction of labor, symptoms and feelings during this phase. The post-natal and breastfeeding meeting raised the issues of childcare, breastfeeding, the use of pacifiers and bottles, as well as legal rights during pregnancy. At the end of the third meeting, women were asked to respond a post-workshop survey, using the same instrument applied before.

Data analysis were performed in SPSS 18.0 (https://www.ibm.com/). Time points (pre and post) were compared using either student $t$ test and ANOVA. To test the homogeneity between surveys the Levene test was performed with $\mathrm{p} \leq 0.05$. To determinate the percentage values gained, the mean results of the post-workshop survey were compared to the pre-workshop survey.

This research was approved by the Human Research Ethics Committee under CAA 69959716.6.0000.5369. 


\section{Results}

For two years, 12 workshops were performed involving 105 women. The majority of the participants were less than 25 years old (51.4\%) and were at their first pregnancy (51.4\%). Most of them had never had a vaginal birth $(74.3 \%)$ or a cesarean $(7.1 \%)$ but four women reported at least one previous miscarriage (11.4\%). The majority of participants were at the first trimester $(82.9 \%)$ and they were all Caucasians. The level of education of the followed patients varied from 6 to 14 years, with mean of 8 \pm 1.3 years of study.

\section{Knowledge of antenatal care}

The lower scored items were about physical exercise and relaxation techniques for pregnancy and methods for preparing the breasts for breastfeeding. The higher score items were about risks caused by cigarettes and alcoholic drinks (Table 1). After the workshop, the level of knowledge increased in all items, almost at the same level. This session's overall score increased 20.4\% ( $<<0.001)$ (Table 2).

\section{Knowledge of labor and delivery}

The lower scored item was also about physical exercise and relaxation techniques for labor. The highest score was about the knowledge of cesarean indication. All items presented higher scores after the workshop (Table 1). The knowledge level in this session increased 36.8\% $(\mathrm{p}<0.001)$ (Table 2).

\section{Knowledge of post-natal care and breastfeeding}

The lower scored items regarded the information about what would be done with the newborn at the delivery room and how to understand his/her crying. The highest score was related to the importance of breastfeeding (Table 1). All items had increased scores after the workshop. The knowledge level in this session increased $32.1 \%(\mathrm{p}<0.001)$ (Table 2$)$

The overall score also increased $(31.7 \%)$ when comparing pre and post applications $(\mathrm{p}<0.001)$ (Table 2). The homogeneity between the two surveys using the total scores from each session and the application in general was also demonstrated $(\mathrm{p}<0.001)$.

Table 1

Score for knowledge by the three sub-groups of information.

\begin{tabular}{|c|c|c|c|c|c|}
\hline \multirow[t]{2}{*}{ Stages of the workshop } & \multicolumn{5}{|c|}{ Numbers and percentages with score at study times } \\
\hline & $\begin{array}{c}\text { Score } 1 / 5 \\
n(\%)\end{array}$ & $\begin{array}{c}\text { Score } 2 / 5 \\
\text { n (\%) }\end{array}$ & $\begin{array}{c}\text { Score } 3 / 5 \\
\text { n (\%) }\end{array}$ & $\begin{array}{c}\text { Score 4/5 } \\
\text { n (\%) }\end{array}$ & $\begin{array}{c}\text { Score 5/5 } \\
\text { n (\%) }\end{array}$ \\
\hline \multicolumn{6}{|l|}{ Antenatal care (8-item) } \\
\hline Pre-workshop & $87(10.4)$ & $51(6.1)$ & $66(7.9)$ & $225(26.8)$ & $411(48.9)$ \\
\hline Post-workshop & $9(1.1)$ & $12(1.4)$ & $18(2.1)$ & $66(7.9)$ & $801(87.5)$ \\
\hline \multicolumn{6}{|l|}{ Labor and delivery (9-item) } \\
\hline Pre-workshop & $198(21.0)$ & $108(11.4)$ & $111(11.8)$ & $201(21.3)$ & $327(34.6)$ \\
\hline Post-workshop & $3(0.3)$ & $9(1.0)$ & $9(1.0)$ & $105(11.1)$ & $819(86.7)$ \\
\hline \multicolumn{6}{|c|}{ Post-natal and breastfeeding (9-item) } \\
\hline Pre-workshop & 135 (14.3) & $120(12.7)$ & $105(11.1)$ & $183(19.4)$ & $402(42.5)$ \\
\hline Post-workshop & $12(1.3)$ & $9(1.0)$ & $6(0.6)$ & $99(10.5)$ & $819(86.7)$ \\
\hline
\end{tabular}




\section{Table 2}

Total scores for knowledge included in the workshop and the comparative analysis from the pre and post-workshop surveys.

\begin{tabular}{lcc}
\hline & Mean \pm SD & 95\%Cl \\
\hline Antenatal care (8-item) & & \\
$\quad$ Pre-workshop & $31.8 \pm 5.8$ & $29.8-33.8$ \\
Post-workshop & $38.3 \pm 4.1$ & $37.0-39.7$ \\
Labor and delivery (9-item) & & \\
$\quad$ Pre-workshop & $31.8 \pm 5.8$ & $29.8-33.8$ \\
$\quad$ Post-workshop & $43.5 \pm 3.3$ & $42.3-44.6$ \\
Post-natal and breastfeeding (9-item) & & \\
$\quad$ Pre-workshop & $32.7 \pm 10.1$ & $29.1-36.2$ \\
$\quad$ Post-workshop & $43.2 \pm 4.9$ & $41.5-44.9$ \\
Total (26-item) & & 8.001 \\
$\quad$ Pre-workshop & $94.9 \pm 22.9$ & $120.9-129.1$ \\
$\quad$ Post-workshop & $125.0 \pm 23.7$ & $<.001$ \\
\hline
\end{tabular}

95\% Cl: 95\% confidence interval; SD: standard deviation.

\section{Discussion}

This study provided evidence that educational intervention can increase knowledge about pregnancy, delivery, breastfeeding and newborn care to pregnant women. This is very important since during the nine months of prenatal care, in the limited time of each medical appointment, it is impossible to provide patients and their families with all necessary information.

The possibility of exchanging experiences and knowledge is considered the best way to promote understanding about the pregnancy process 7,8 . Popular health education is the most democratic way to construct a broad concept of health, to promote self-care and to improve public health ${ }^{9}$. Sociological approaches that favor the analysis of the processes of medicalization and humanization in a connected way have been little explored and could address extra dimensions in the understanding of the themes and problems specific to pregnancy ${ }^{9}$.

Establishing a link between pregnant women and health care providers is important however no scientific articles were found indicating structured protocols for educational activities such as this workshop 7,8,9.

A recent meta-analysis identified several variables associated with an increase in health facility delivery, including the parents' educational status as the main predictor 10 . The development of educational strategies has been recommended for even more specific purposes, such as increasing breastfeeding rates or implementing oral health care in pregnant women 10.

Prenatal breastfeeding education increases breastfeeding initiation, exclusivity, and duration, Women successfully learn breastfeeding content via computer and tablets in the northeast United States 11.

In Latin America, the acceptability of an interactive computer kiosk that provided environmental health education to low-income prenatal patients brought an innovative modality 12. In Brazil, similar experiences demonstrate the increase of perinatal outcomes using new technologies to educate pregnant women 13. Great and modern devices are not necessary. Orientation and preparation of pregnant women about good practices in assisting the delivery process can be achieved with simple technologies 10,11.

Group meetings of pregnant women with partner participation help to clarify doubts, reassure fears and guide the knowledge of the physiological changes during pregnancy.

For future studies, mixed qualitative and quantitative studies, it might be interesting to hear from the women's own voice what they have discovered in this learning process. The quantitative data do not allow to portray the complexity of the problem addressed. 


\section{Conclusion}

Workshops may increase pregnancy knowledge regarding antenatal care, labor, delivery, post-natal care and breastfeeding. However, the post-test responses were given immediately after the exposure to the information, without the guarantee of the maintenance of that effect. For this reason, these patients are intended to be followed up in a cohort to investigate the effect of this knowledge in the long term.

\section{Contributors}

R. D. Nunes contributed in the preparation and execution of workshops, data collection, calculations, paper writing. A. G. Puel participated in the workshop execution and in the preparation of the paper. N. Gomes participated in the workshop and contributed writing the paper. J. Traebert contributed writing this article, mainly the results and the discussion.

\section{References}

1. Willcox JC, Ball K, Campbell KJ, Crawford DA, Wilkinson SA. Correlates of pregnant women's gestational weight gain knowledge. Midwifery 2017; 49:32-9.

2. Sriprasert I, Chaovisitsaree S, Sribanditmongkhol N, Sunthornlimsiri N, Kietpeerakool C. Unintended pregnancy and associated risk factors among young pregnant women. Int J Gynaecol Obstet 2015; 128:228-31.

3. Irving G, Neves AL, Dambha-Miller H, Oishi A, Tagashira H, Verho A, et al. International variations in primary care physician consultation time: a systematic review of 67 countries. BMJ Open 2017; 7:e017902.

4. Wang X, Guo G, Liang X, Zhou L, Zheng J, Li $S$, et al. Health utility of pregnant women living with HIV/AIDS: prevention of mother-tochild transmission of HIV (PMTCT) programs in Yunnan Province: a cross-sectional study. Value Health Reg Issues 2018; 15:27-33.

5. Almeida NKO, Pedreira CE, Almeida RMVR. Impact of maternal education level on risk of low Apgar score. Public Health 2016; 140:244-9.

6. Dowswell T, Carroli G, Duley L, Gates S, Gülmezoglu AM, Khan-Neelofur D, et al. Alternative versus standard packages of antenatal care for low-risk pregnancy. Cochrane Database Syst Rev 2015; (7):CD000934.

7. Warland J, Glover P. Talking to pregnant women about stillbirth: Evaluating the effectiveness of an information workshop for midwives using pre and post intervention surveys. Nurse Educ Today 2015; 35:e21-5.

\section{Additional informations}

ORCID: Rodrigo Dias Nunes (0000-0002-22618253); Ana Gabriela Puel (0000-0001-6164-3390); Natália Gomes (0000-0003-0286-4446); Jefferson Traebert (0000-0002-7389-985X).

8. Alves FLC, Castro EM, Souza FKR, Lira MCPS, Sampaio FLR, Pereira LP. Grupo de gestantes de alto-risco como estratégia de educação em saúde. Rev Gaúch Enferm 2019; 40:e20180023.

9. Warmling CM, Fajardo AP, Meyer DE, Bedos C. Práticas sociais de medicalização \& humanização no cuidado de mulheres na gestação. Cad Saúde Pública 2018; 34:e00009917.

10. Hughes O, Mohamad MM, Doyle P, Burke G. The significance of breastfeeding on sleep patterns during the first 48 hours postpartum for first time mothers. J Obstet Gynaecol 2018; 38:316-20.

11. Suárez-Cotelo MDC, Movilla-Fernández MJ, Pita-García P, Fernández Arias B, Novío S. Breastfeeding knowledge and relation to prevalence. Rev Esc Enferm USP 2019; 53:e03433.

12. Nunes Neto RA, Frutuoso MFP. Oral health and the care of pregnant women: workshops as a strategy to problematize practices in basic health care in residents living in the peripheral areas of the hills in the city of Santos. Rev Gaúch Odontol 2018; 66:305-16.

13. Wallenborn JT, Lu J, Perera RA, Wheeler DC, Masho SW. The impact of the professional qualifications of the prenatal care provider on breastfeeding duration. Breastfeed Med 2018; 13:106-11. 


\section{Resumo}

$O$ artigo relata os achados de uma intervenção educativa através de uma oficina para fornecer informações às mulheres sobre a gravidez, parto, aleitamento e cuidados do recém-nascido. Foi realizado um estudo transversal com um desenho de pesquisa de intervenção, com 105 gestantes usuárias de um serviço obstétrico, ao longo de dois anos. Os dois momentos (pré-e pós-intervenção) foram comparados com o uso do teste $t$ de Student ou ANOVA, com nível de significância de $p \leq 0,05$. Após a intervenção, todos os itens aumentaram de nível nas três dimensões: atendimento pré-natal (20,4\%), trabalho de parto e nascimento $(36,8 \%)$ e pós-parto e aleitamento (32,1\%). A pontuação total dos inquéritos também aumentou em 31,7\% na comparação das aplicações pré e pós-intervenção $(p<0,001)$. Ficou evidenciada a importância de estratégias para melhorar o conhecimento das gestantes sobre a gravidez e seu entorno. A proposta da oficina resultou em aumento nesse conhecimento e deverá trazer melhores resultados no curto e longo prazo.

Gestantes; Educação em Saúde; Complicações na Gravidez; Aleitamento Materno

\section{Resumen}

Este trabajo informa sobre los resultados de una intervención educacional, llevada a cabo a través de un taller impartido para proporcionar a mujeres embarazadas conocimientos sobre el embarazo, parto, lactancia materna y cuidados de un recién nacido. Se realizó un estudio transversal, usando un diseño de investigación de pre-y pos-intervención, realizado con 105 mujeres embarazadas procedentes de un servicio obstétrico durante un periodo de dos años. Los puntos temporales (pre y post) se compararon usando bien el Student t test o bien ANOVA. La significancia se estableció en $p \leq 0,05$. Tras la intervención todos los items incrementaron su nivel en los tres estadios: cuidado prenatal (20.4\%), trabajo de parto y parto (36.8\%), así como cuidados postnatales y lactancia materna (32.1\%). La puntuación total de los estudios también se incrementó un 31,7\%, si comparamos las pre-y post-aplicaciones $(p<0.001)$. Se evidenció la importancia de las estrategias para mejorar el conocimiento sobre el embarazo y todo lo que rodea a una mujer embarazada. La propuesta del taller presentó un aumento del conocimiento sobre estos temas y, probablemente, puede brindar mejores resultados en los resultados a corto y largo plazo sobre estas cuestiones.

Mujeres Embarazadas; Educación en Salud; Complicaciones del Embarazo; Lactancia

Materna
Submitted on $07 /$ Aug/2018

Final version resubmitted on 29/Jul/2019

Approved on 05/Aug/2019 